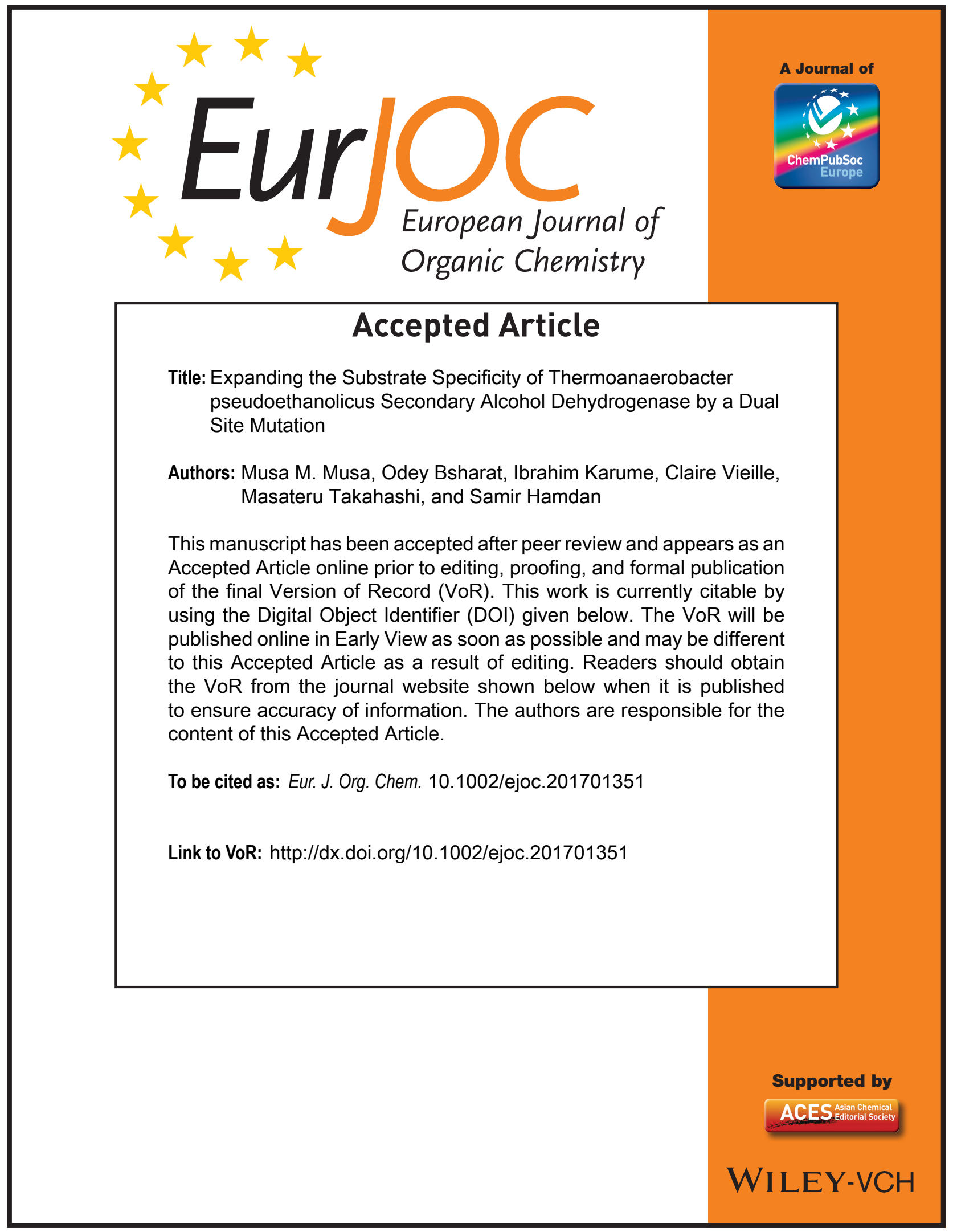




\title{
Expanding the Substrate Specificity of Thermoanaerobacter pseudoethanolicus Secondary Alcohol Dehydrogenase by a Dual
}

\section{Site Mutation}

\author{
Musa M. Musa, ${ }^{*[a]}$ Odey Bsharat, ${ }^{[a]}$ Ibrahim Karume, ${ }^{[a]}$ Claire Vieille,${ }^{[b]}$ Masateru Takahashi, ${ }^{[c]}$ and \\ Samir M. Hamdan ${ }^{[c]}$
}

\begin{abstract}
Here, we report the asymmetric reduction of selected phenyl-ring-containing ketones by various single and dual site mutants of Thermoanaerobacter pseudoethanolicus secondary alcohol dehydrogenase (TeSADH). Further expanding the size of the substrate binding pocket in the mutant W110A/I86A not only allowed substrates of the single mutants $\mathrm{W} 110 \mathrm{~A}$ and $186 \mathrm{~A}$ to be accommodated within the expanded active site, but also expanded the enzyme's substrate range to ketones bearing two sterically demanding groups (bulky-bulky ketones), which are not substrates for TeSADH single mutants. We also report the regio- and enantioselective reduction of diketones using W110A/I86A TeSADH and single TeSADH mutants. The double mutant exhibited dual stereopreference generating the Prelog products most of the time and the anti-Prelog products in a few cases.
\end{abstract}

\section{Introduction}

Optically-active alcohols are important precursors in the agrochemical and pharmaceutical industries. These building blocks can be synthesized by chemical means using chiral transition metal catalysts that are expensive and require sophisticated reaction conditions. An alternative biocatalytic approach is preferable because enzymes are not only highly chemo-, regio-, and stereoselective, they are also economical and environmentally benign. ${ }^{[1]}$ Enzyme-catalyzed reactions are carried out under mild conditions, which minimize by-products formation by reducing the possibility of isomerization, racemization, and epimerization. ${ }^{[2]}$ Still, enzyme-based approaches have disadvantages: enzymes may be insufficiently stable for commercial applications, and reaction products might

[a] Prof. M. M. Musa, O. Bsharat, Dr. I. Karume Chemistry Department

King Fahd University of Petroleum and Minerals Dhahran, 31261, KSA

E-mail:musam@kfupm.edu.sa

http://faculty.kfupm.edu.sa/CHEM/musam/index.html

[b] Prof. C. Vieille

Department of Microbiology and Molecular Genetics and

Department of Biochemistry and Molecular Biology

Michigan State University

East Lansing, MI 48824, USA

[c] Dr. M. Takahashi, Prof. S. M. Hamdan

Division of Biological and Environmental Sciences and Engineering

King Abdullah University of Science and Technology

Thuwal, 23955-6900, KSA

Supporting information for this article is given via a link at the end of the document. accumulate only in small concentrations, which complicates their recovery. ${ }^{[2]}$ Synthesis of optically-active alcohols from prochiral ketones using enzymes has been extensively studied. ${ }^{[3]}$ Alcohol dehydrogenases (ADHs) are an important class of enzymes, in which nicotinamide-adenine dinucleotide $\left(\mathrm{NAD}^{+}\right)$or its phosphate derivative $\left(\mathrm{NADP}^{+}\right)$acts as a cofactor. $\mathrm{ADHs}$, either in whole cells or as purified enzymes, have been extensively used to produce enantiopure alcohols. Among those are ADHs from Thermoanaerobium brockii (TbSADH), ${ }^{[4]}$ Rhodococcus ruber, ${ }^{[5]}$ Candida magnolia, ${ }^{[6]}$ Lactobacillus kefir,${ }^{[7]}$ and horse liver, ${ }^{[8]}$ to name a few.

Thermoanaerobacter pseudoethanolicus secondary $\mathrm{ADH}$ (TeSADH, EC 1.1.1.2) is identical in sequence to the well-known and commercially available TbSADH, ${ }^{[9]}$ Both enzymes are $\mathrm{NADP}^{+}$-dependent, and have been successfully employed in the reversible asymmetric reduction of ketones. ${ }^{[10,11]}$ These enzymes gained significant interest because of their high thermal stability and tolerance to elevated concentrations of organic solvents. ${ }^{[12]}$ However, like other ADHs, TeSADH and TbSADH suffer from high substrate specificity (i.e., limited substrate scope). ${ }^{[13]}$ TeSADH's substrate binding site comprises two pockets of different sizes and affinities. ${ }^{[10 \mathrm{~b}, 11]}$ Phenyl-ring-containing ketones and their corresponding alcohols are not substrates for wild-type TeSADH. ${ }^{[13]}$

Expanding TeSADH's substrate scope would widen its applicability as a biocatalyst. Site-directed mutagenesis of TeSADH has expanded its substrate range to a certain extent and modified its stereoselectivity. ${ }^{[11]}$ In particular, mutations of W110, which lines the substrate binding site, allowed for the asymmetric reduction of 4-phenyl-2-butanone and 1-phenyl-2-propanone and their analogs, but not acetophenone (Scheme 1). ${ }^{[14]}$ The stereochemical outcome of redox reactions catalyzed by TeSADH and its W110 mutants obeys Prelog's rule,${ }^{[15]}$ in which the pro- $R$ hydride of NADPH is delivered to the Re face of a prochiral ketone, producing $S$ alcohols. Mutation I86A was designed to expand what has been called the small pocket in the substrate binding site. ${ }^{16]}$ I86A TeSADH reduced acetophenone analogs in antiPrelog mode, but could not reduce 4-phenyl-2-butanone and 1phenyl-2-propanone. None of these single TeSADH mutants accommodated bulk-bulky ketones that are precursors to pharmaceutically important analogs such as optically-active 1,2diarylethanols, which are analogs of the anti-cancer agent, combretastatin (Figure 1). ${ }^{[17]}$ Few reports have been published on the asymmetric reduction of such bulky-bulky ketones using either whole cells ${ }^{[18]}$ or purified enzymes. ${ }^{[19]}$ Developing a TeSADH mutant that can accommodate a wide scope of substrates is of interest to advance this robust enzyme. 


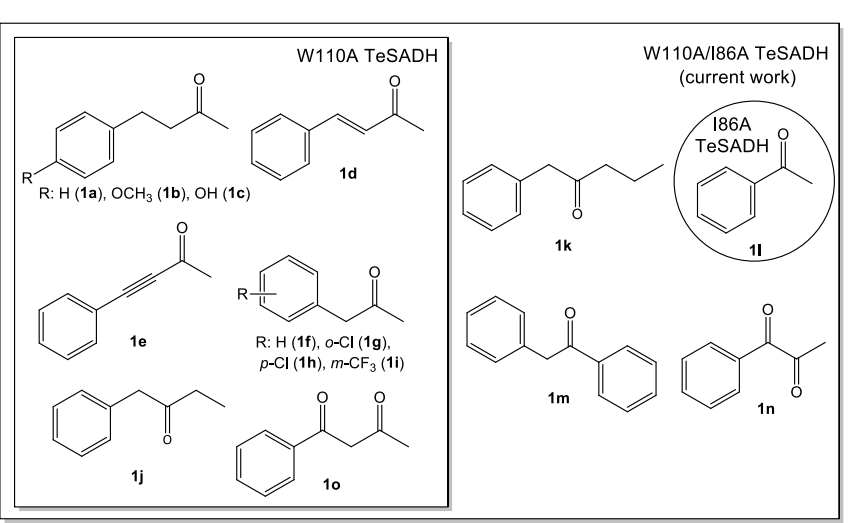

Scheme 1. Ketones used in this study.

To expand substrate specificity of TeSADH and thus make it a more attractive biocatalyst, we built the W110A/I86A TeSADH double mutant. W110 and I86 line the large and the small pockets, respectively, of TeSADH's substrate binding site, and thus mutation of these two residues to Ala is expected to expand both binding pockets. This double mutation not only expanded the substrate scope of TeSADH to accommodate diaryl ketone substrates, but it also altered the enzyme's stereoselectivity for a few substrates. We also compared the performance of this double mutant with those of single TeSADH W110 mutants and performed docking studies of 1,2-diphenylethanone in the W110A/I86A TeSADH active site.<smiles>COc1ccc(C[C@H](O)c2cc(OC)c(OC)c(OC)c2)cc1O</smiles><smiles>O=CO[C@H]1CCOC1</smiles>

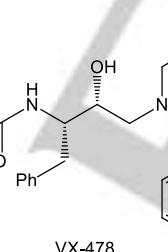<smiles>Clc1ccc2ccccc2n1</smiles><smiles>C=CC(=O)N[C@@H](CC(N)=O)C(N)=O</smiles>
$5-52151$

Figure 1. Chemical structures of $(R)$-combretastatin, VX-478, and SC-52151.

\section{Results and Discussion}

To check the efficiency of W110A/I86A TeSADH in the asymmetric reduction of phenyl-ring-containing ketones that are substrates for W110A TeSADH, ${ }^{[14 b]}$ we conducted a comprehensive study of the activity and stereoselectivity of various W110 mutants (W110A, W110G, and W110V) as well as W110A/I86A TeSADH in asymmetric reduction of these ketones. Unless otherwise mentioned, reactions were performed in tris(hydroxymethyl)aminomethane- $\mathrm{HCl}$ (Tris- $\mathrm{HCl}$ ) containing 2propanol $(30 \%, v / v)$, which works as a co-solvent and a cosubstrate. Although the asymmetric reductions of 4-phenyl-2butanone (1a), 4-(4'-methoxyphenyl)-2-butanone (1b), 4-phenyl3-buten-2-one (1d), 1-phenyl-2-propanone (1f), and 1-phenyl-2butanone (1j) using W110A TeSADH, as well as those of 1a and 1f using W110G and W110V TeSADHs, have already been reported, ${ }^{[14]}$ we screened the asymmetric reduction of these substrates using the aforementioned mutants under the conditions used in the current study to allow proper comparison. The discrepancies in enantioselectivities between the results reported here and earlier are due to the different reaction conditions used. ${ }^{20]}$

The four mutants tested showed similar catalytic properties in the asymmetric reduction of $\mathbf{1 a}$, producing (S)-4-phenyl-2butanol $[(S)-2 a]$ with high conversion yields and enantioselectivities (Table 1). Optically-active $\mathbf{2 a}$ is a synthon in protease inhibitors such as VX-478 and SC-52151 (Figure 1), which are potential therapeutic agents for the treatment of acquired immunodeficiency syndrome (AIDS). ${ }^{[21]}$ Single TeSADH mutants W110A, W110G, and W110V showed a slight edge in conversion yield over the double mutant (W110A/I86A) in the asymmetric reductions of $\mathbf{1 b}$ and 4-(4'-hydroxyphenyl)-2butanone (1c). However, W110A/I86A TeSADH showed a higher stereoselectivity than the single mutants did in the asymmetric reduction of $\mathbf{1 b}$ (Table 1). W110G TeSADH showed the least stereoselectivity in the reduction of $\mathbf{1 b}$, which is consistent with previously reported results for asymmetric reduction of $\mathbf{1 a} .^{[14 a]}$ It is well noted that the conversion yield and stereoselectivity of TeSADH-catalyzed reduction reactions are highly dependent on the structures of both the enzyme's active site and the substrate. The high percent ee $(>94 \%)$ registered in the asymmetric reduction of 1c using all TeSADH mutants when compared with $\mathbf{1 b}$ could be due to higher binding affinity of 1c's hydroxyl group for the enzyme active site compared to $\mathbf{1 b}$ 's methoxy group, which results in fewer selectivity mistakes in 1c reduction. (S)-1c, known as $(S)$-rhododendrol, has been used to prevent hepatotoxicity ${ }^{[22]}$ and as melanin-inhibitor in skin-lightening cosmetics. ${ }^{[23]} A$ low conversion yield was observed in the W110A/I86A TeSADHcatalyzed reduction of $\mathbf{1} \mathbf{d}$ compared to those obtained with single mutants (Table 1). However, the asymmetric reduction of 4phenyl-3-butyn-2-one (1e) resulted in high conversion yield and high ee with all mutants. The asymmetric reduction of $1 \mathrm{e}$ with high enantioselectivity is of great interest as this substrate, known as a difficult substrate, is not easily reduced with high enantioselectivity. ${ }^{[24,25]}$ During optimization of the co-substrate concentration, we observed an increase in stereoselectivity in the asymmetric reduction of $\mathbf{1 b}$ and $\mathbf{1 c}$ when using $10 \%(\mathrm{v} / \mathrm{v})$ instead of $30 \%(\mathrm{v} / \mathrm{v})$ 2-propanol, as used for 1a, 1d and 1e; this effect could be due to differences in TeSADH's active site solvation affecting substrate binding affinity. ${ }^{[26]}$ 
Table 1. Asymmetric reduction of phenyl-ring-containing ketones by the TeSADH mutants. ${ }^{[a]}$

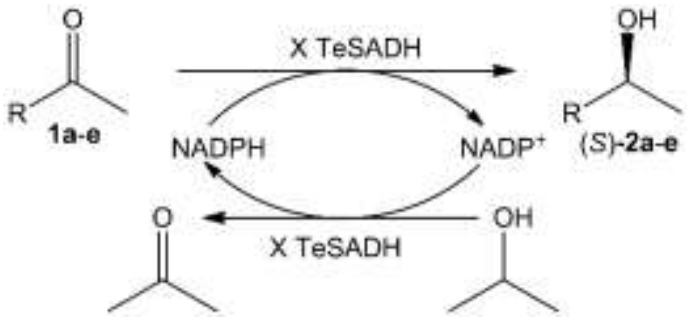

\begin{tabular}{|c|c|c|c|c|}
\hline $\mathrm{R}$ & Substrate & $x$ & $\begin{array}{l}\text { Conv. } \\
(\%)^{[b]}\end{array}$ & $\begin{array}{c}e e \\
(\%)^{[\mathrm{c}]}\end{array}$ \\
\hline \multirow{4}{*}{$\mathrm{PhCH}_{2} \mathrm{CH}_{2}$} & 1a & W110G & $>99$ & 96 \\
\hline & & W110A & 99 & 99 \\
\hline & & W110V & 95 & $>99$ \\
\hline & & W110A/l86A & 91 & 98 \\
\hline \multirow[t]{4}{*}{$p-\mathrm{MeO}-\mathrm{C}_{6} \mathrm{H}_{4}-\mathrm{CH}_{2} \mathrm{CH}_{2}$} & $1 b^{[d]}$ & W110G & 93 & 20 \\
\hline & & W110A & 98 & 60 \\
\hline & & W110V & 94 & 79 \\
\hline & & W110A/I86A & 40 & 84 \\
\hline \multirow[t]{4}{*}{$p-\mathrm{HO}-\mathrm{C}_{6} \mathrm{H}_{4}-\mathrm{CH}_{2} \mathrm{CH}_{2}$} & $1 c^{[d]}$ & W110G & 95 & 99 \\
\hline & & W110A & 97 & $>99$ \\
\hline & & W110V & 92 & 94 \\
\hline & & W110A/l86A & 80 & $>99$ \\
\hline \multirow[t]{4}{*}{$(E)-\mathrm{Ph}-\mathrm{HC}=\mathrm{CH}$} & 1d & W110G & 75 & $>99$ \\
\hline & & W110A & 73 & 92 \\
\hline & & W110V & 67 & 92 \\
\hline & & W110A/I86A & 21 & 90 \\
\hline \multirow[t]{4}{*}{$\mathrm{Ph}-\mathrm{C} \equiv \mathrm{C}$} & $1 e$ & W110G & $>99$ & 97 \\
\hline & & W110A & 99 & 99 \\
\hline & & W110V & 97 & $>99$ \\
\hline & & W110A/I86A & $>99$ & 98 \\
\hline
\end{tabular}

[a] Unless otherwise stated, reactions were performed using $0.0191 \mathrm{mmol}$ ketone $1 \mathrm{a}-\mathbf{e}, 100 \mu \mathrm{L}$ enzyme [0.2 mg])], $1.0 \mathrm{mg} \mathrm{NADP}^{+}, 600 \mu \mathrm{L}$ buffer $\mathrm{A}$ and $300 \mu \mathrm{L} 2$-propanol; for $\mathrm{W} 110 \mathrm{~A} / \mathrm{l} 86 \mathrm{~A}$ TeSADH-catalyzed reactions, $\mathrm{ZnCl}_{2}$ and DTT were added at $1.4 \mu \mathrm{M}$ and $6.5 \mathrm{mM}$ final concentrations, respectively; the $\mathrm{W} 110 \mathrm{~V}$ TeSADH-catalyzed reactions contained 0.0038 mmol 1a-e , $950 \mu \mathrm{L}$ buffer $\mathrm{A}$, and $50 \mu \mathrm{L}$ 2-propanol. [b] Percent conversion was determined by Gas chromatography (GC). [c] The \% ee of the acetate ester derivative of the alcohol produced was determined by GC using a chiral stationary phase. [d] Reactions were performed using 10\% 2-propanol.

Reduction of substrates 1a-e using W110A/I86A TeSADH followed Prelog mode, consistent with the results obtained with W110 single mutants. The ability of W110A/I86A TeSADH to reduce these substrates with efficiencies similar to those obtained with the single mutants is exciting. Note that $\mathrm{W} 110 \mathrm{~A} / \mathrm{l} 86 \mathrm{~A}$ TeSADH was first designed to enlarge the two substrate-binding pockets to increase the efficiency of enantiopure alcohol racemization by increasing selectivity mistakes. ${ }^{[27]}$ Yet, W110A/I86A TeSADH shows enantioselectivity comparable to the single mutants, which indicates that the size of the substratebinding site is not the only factor that controls stereoselectivity of TeSADH-catalyzed reactions.

Previously, ${ }^{[14]}$ we observed that the asymmetric reduction of 1 using the W110G and W110A TeSADH mutants produced (S)- 2f with excellent conversion yields and moderate ees, and that using $\mathrm{W} 110 \mathrm{~V}$ TeSADH resulted in a significant improvement in ee (>99\%). One possible explanation is that 1f can fit in two orientations in the large binding pocket of W110A and W110G TeSADHs; but a single orientation is allowed in W110V, whose large pocket is smaller than that of the W110A and W110G mutants. Interestingly, in the current report, the W110A/I86A TeSADH-catalyzed reduction of $\mathbf{1 f}$ resulted in a reverse stereochemical outcome, producing $(R)$-2f with high conversion yield and good enantioselectivity (Table 2). Both substratebinding pockets are enlarged in the double mutant, likely allowing the benzyl group of $\mathbf{1 f}$ to fit in either pocket.

Asymmetric reduction of 2-chlorophenylacetone (1g) by the single mutants produced (S)-2 $\mathbf{g}$ with high enantioselectivity. In contrast, W110A/I86A TeSADH produced the opposite enantiomer $(R)-2 \mathrm{~g}$ with high ee $(99 \%)$. Reduction of 4chlorophenylacetone $(\mathbf{1 h})$ resulted in $(S)-2 \mathbf{h}$ irrespective of the enzyme used, which demonstrates the importance of the substituent location on the phenyl ring in controlling stereoselectivity. The presence of a trifluoromethyl group in the meta position in 3-(trifluoromethyl)phenylacetone (1i) resulted in reduction to $(S)-2 \mathbf{i}$ with high conversion yield and high enantioselectivity using all mutants, which indicates that the $\mathrm{CF}_{3}$ in meta position does not allow $1 \mathrm{i}$ to fit within the small pocket of W110A/I86A TeSADH as $\mathbf{1 f}$ and $\mathbf{1 g}$ do. Reduction of $\mathbf{1 j}$ predominantly produced the $S$-alcohol in high ees using the single mutants and a moderate ee using the double mutant. The moderate enantioselectivity of the W110A/l86A TeSADHcatalyzed asymmetric reduction of $1 \mathbf{j}$ could be due to the ability of the benzyl group to fit in the small pocket, leading to noticeable selectivity mistakes. Extending the alkyl moiety to propyl in 1phenyl-2-pentanone $(\mathbf{1 k})$ resulted in a reversed fit of this substrate in the active site of $\mathrm{W} 110 \mathrm{~A} / \mathrm{l} 6 \mathrm{~A}$ TeSADH producing $(R)-\mathbf{2 k}$ in high ee. This result indicates that the propyl group forces this substrate to fit in an orientation that allows for a Si-face attack of the ketone by the hydride of NADPH in anti-Prelog mode. Surprisingly, we also observed this reversed stereochemistry in $\mathbf{1 k}$ reduction by $\mathrm{W} 110 \mathrm{~V}$ TeSADH with low conversion yield. $\mathbf{1 k}$ was not a substrate for W110G and W110A TeSADHs.

Table 2. Asymmetric reduction of phenyl ring-containing ketones by the TeSADH mutants. ${ }^{[a]}$

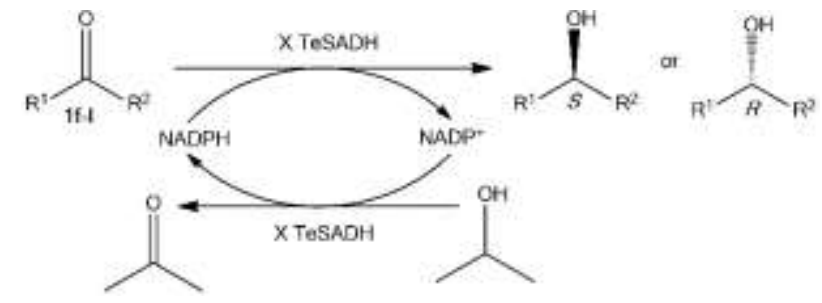

\begin{tabular}{lccccc}
\hline $\mathrm{R}^{1}$ & $\mathrm{R}^{2}$ & Substrate & $\mathrm{X}$ & $\begin{array}{l}\text { Conv. } \\
(\%)^{[\mathrm{b}]}\end{array}$ & $\begin{array}{l}\text { ee } \\
(\%)^{[\mathrm{c}]}\end{array}$ \\
\hline $\mathrm{PhCH}_{2}$ & $\mathrm{CH}_{3}$ & \multirow{2}{*}{ 1f } & $\mathrm{W} 110 \mathrm{G}$ & $>99$ & $79(S)$ \\
& & & $\mathrm{W} 110 \mathrm{~A}$ & 95 & $84(S)$ \\
& & & W110V & $>99$ & $>99(S)$ \\
& & & W110A/l86A & $>99$ & $80(R)$
\end{tabular}




\begin{tabular}{|c|c|c|c|c|c|}
\hline \multirow[t]{4}{*}{$o-\mathrm{Cl}-\mathrm{C}_{6} \mathrm{H}_{4}-\mathrm{CH}_{2}$} & \multirow[t]{4}{*}{$\mathrm{CH}_{3}$} & \multirow[t]{4}{*}{$1 \mathrm{~g}$} & W110G & 13 & $89(S)$ \\
\hline & & & W110A & 84 & $98(S)$ \\
\hline & & & W110V & 99 & $>99(S)$ \\
\hline & & & W110A/186A & $>99$ & $99(R)$ \\
\hline \multirow[t]{4}{*}{$p-\mathrm{Cl}-\mathrm{C}_{6} \mathrm{H}_{4}-\mathrm{CH}_{2}$} & \multirow[t]{4}{*}{$\mathrm{CH}_{3}$} & \multirow[t]{4}{*}{$1 \mathrm{~h}$} & W110G & 70 & $89(S)$ \\
\hline & & & W110A & $>99$ & $97(S)$ \\
\hline & & & W110V & $>99$ & $98(S)$ \\
\hline & & & W110A/l86A & 99 & $80(S)$ \\
\hline \multirow{4}{*}{$\begin{array}{l}m-\mathrm{CF}_{3}-\mathrm{C}_{6} \mathrm{H}_{4^{-}} \\
\mathrm{CH}_{2}\end{array}$} & \multirow[t]{4}{*}{$\mathrm{CH}_{3}$} & \multirow[t]{4}{*}{$1 \mathrm{i}$} & W110G & $>99$ & $96(S)$ \\
\hline & & & W110A & $>99$ & $>99(S)$ \\
\hline & & & W110V & 99 & $99(S)$ \\
\hline & & & W110A/186A & $>99$ & $95(S)$ \\
\hline \multirow[t]{4}{*}{$\mathrm{PhCH}_{2}$} & \multirow[t]{4}{*}{$\mathrm{CH}_{3} \mathrm{CH}_{2}$} & \multirow[t]{4}{*}{$1 \mathrm{j}$} & W110G & 96 & $92(S)$ \\
\hline & & & W110A & 98 & $92(S)$ \\
\hline & & & W110V & 99 & $>99(S)$ \\
\hline & & & W110A//86A & 72 & $71(S)$ \\
\hline \multirow[t]{4}{*}{$\mathrm{PhCH}_{2}$} & \multirow{4}{*}{$\begin{array}{l}\mathrm{CH}_{3} \mathrm{CH}_{2} \\
\mathrm{CH}_{2}\end{array}$} & \multirow[t]{4}{*}{$1 \mathrm{k}$} & W110G & n.r. & - \\
\hline & & & W110A & 3 & n.d. \\
\hline & & & W110V & 32 & $92(R)$ \\
\hline & & & W110A//86A & 95 & $98(R)$ \\
\hline \multirow[t]{4}{*}{$\mathrm{Ph}$} & \multirow[t]{4}{*}{$\mathrm{CH}_{3}$} & \multirow[t]{4}{*}{11} & W110G & n.r. & - \\
\hline & & & W110A & n.r. & - \\
\hline & & & W110V & n.r. & \\
\hline & & & W110A/186A & 46 & $98(R)$ \\
\hline
\end{tabular}

[a] Reactions were performed using $0.0191 \mathrm{mmol}$ ketones $1 \mathrm{f}-\mathrm{I}, 0.2 \mathrm{mg}$ enzyme, $1.0 \mathrm{mg} \mathrm{NADP}+, 700 \mu \mathrm{L}$ buffer $\mathrm{A}$, and $300 \mu \mathrm{L}$ 2-propanol; for W110A/186A TeSADH-catalyzed reactions, $\mathrm{ZnCl}_{2}$ and DTT were added at $1.4 \mu \mathrm{M}$ and $6.5 \mathrm{mM}$ final concentrations, respectively; the W110V TeSADHcatalyzed reactions contained $0.0038 \mathrm{mmol} 1 \mathrm{1f}-\mathrm{I}, 950 \mu \mathrm{L}$ buffer A, and $50 \mu \mathrm{L}$ 2-propanol. [b] Percent conversion was determined by GC. [c] The \% ee of the acetate ester derivative of the alcohol produced was determined by GC using a chiral stationary phase. [n.r.: no reaction, n.d.: not determined].

Acetophenone (1I) is not a substrate for wild-type TeSADH or for any of the W110 mutants. 1I was previously shown to be a substrate for $186 \mathrm{~A}$ TeSADH. ${ }^{[16]}$ Its reduction by $\mathrm{W} 110 \mathrm{~A} / \mathrm{I86A}$ TeSADH resulted in $(R)$-1-phenylethanol $[(R)-2 \mathbf{l}]$ in high enantioselectivity and moderate conversion, as shown in Table 2. This outcome is consistent with that observed with I86A TeSADH, which reduced $\mathbf{1 I}$ in anti-Prelog mode. ${ }^{[16]} \mathbf{1 a - j}$ are substrates for W110 TeSADH mutants, but not for I86A TeSADH. In contrast, 1I is a substrate for I86A TeSADH but not for the W110 TeSADH mutants. ${ }^{[28]}$ The $\mathrm{W} 110 \mathrm{~A} / \mathrm{I86A}$ double TeSADH mutant, though, can reduce ketones that are substrates for all individual mutants. This striking finding prompted us to look for other valuable substrates like bulky-bulky ketones to expand TeSADH's substrate range.

The enlarged substrate binding site in $\mathrm{W} 110 \mathrm{~A} / \mathrm{I} 6 \mathrm{AA}$ TeSADH makes this enzyme mutant a potential catalyst to reduce bulky-bulky ketones such as 1,2-diphenylethanone (1m) (Table 3), which is not a substrate for any previously reported mutant of TeSADH including W110 mutants. Reduction of $1 \mathrm{~m}$ using W110A/I86A TeSADH resulted in $(R)-2 \mathrm{~m}$ in high enantioselectivity and high conversion yield. The ability of W110A/I86A TeSADH to accommodate $\mathbf{1 m}$ is attributed to extensions of both its small and large substrate-binding pockets. Reduction of $1 \mathrm{~m}$ by W110A/I86A TeSADH followed Prelog's rule with an inverted Cahn-Ingold-Prelog priority, which indicates that the benzyl group binds in the large pocket and the phenyl group binds in the small pocket. Reduction of such bulky-bulky substrate with high enantioselectivity is of great interest because the similar sizes of the phenyl and benzyl moieties do not guide the binding based on pocket size only. The conversion yield for the reductions of the bulky-bulky substrate $1 \mathrm{~m}$ by $\mathrm{W} 110 \mathrm{~A} / \mathrm{I86A}$ TeSADH was clearly about 2-fold higher than that for 11 , which is a typical example of a small-bulky ketone; this result could be due to a good fit of bulky-bulky substrates within the active site of W110A/l86A TeSADH that allows for maximum utilization of the active site.

Table 3. Asymmetric reduction of 1,2-diphenylethanone by $\mathrm{W} 110 \mathrm{~A} / \mathrm{l} 6 \mathrm{~A}$ TeSADH. ${ }^{[\mathrm{a}]}$

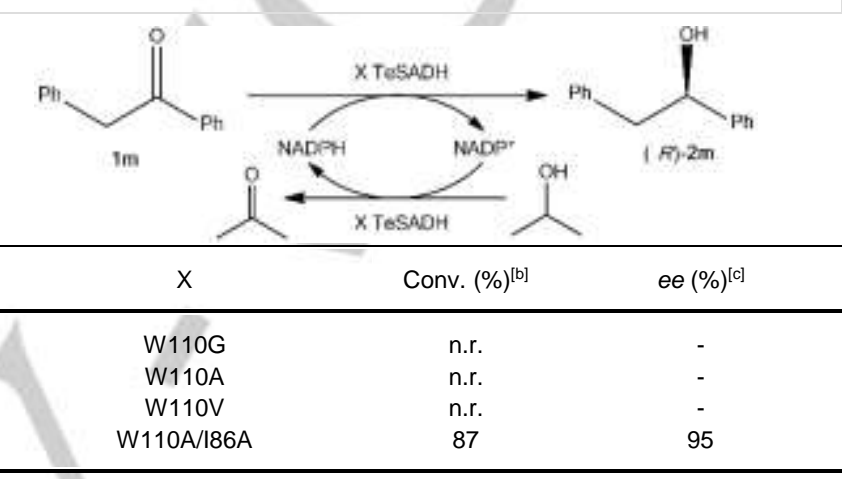

[a] Reaction mixtures contained $0.0191 \mathrm{mmol} 1 \mathrm{~m}, 0.4 \mathrm{mg}$ enzyme, $1.0 \mathrm{mg}$ $\mathrm{NADP}^{+}, 700 \mu \mathrm{L}$ buffer A, $300 \mu \mathrm{L}$ 2-propanol, and $\mathrm{ZnCl}_{2}$ and DTT to final concentrations of $1.4 \mu \mathrm{M}$ and $6.5 \mathrm{mM}$, respectively. [b] Percent conversion was determined by GC. [c] The \% ee for $(R)-2 \mathrm{~m}$ was determined by highperformance liquid chromatography (HPLC) using hexane/methanol $(\mathrm{v} / \mathrm{v}=$ 95: 5). [n.r.: no reaction].

The binding orientation of $1 \mathrm{~m}$ in W110A/I86A TeSADH was confirmed by computational docking (Figure $2 \mathrm{~A}$ ) using the crystal structure of TbSADH (identical in sequence to TeSADH ${ }^{[9]}$ ) in complex with NADP as the template. The lowest binding energy configuration $(-5.9 \mathrm{~kJ} / \mathrm{mol})$ placed $1 \mathrm{~m}$ 's phenyl ring in the small pocket and the carbonyl group at $3.7 \AA$ from His59. The carbonyl is unusually far from His59 for catalysis, but this distance likely explains why the $1 \mathrm{~m}$ reduction reaction required double the amount of enzyme compared to most other conversions in this study, and why, even with extra enzyme, the $1 \mathrm{~m}$ reduction reaction did not reach full completion (Table 2). In comparison, the lowest energy docking of $1 \mathrm{~m}$ in W110A TeSADH $(-5.1 \mathrm{~kJ} / \mathrm{mol})$ placed the carbonyl $4.0 \AA$ away from His59 (Figure $2 \mathrm{~B}$ ), and the lowest energy docking of $1 \mathrm{~m}$ in W110V TeSADH $(-1.8 \mathrm{~kJ} / \mathrm{mol})$ created a steric clash with F112 (not shown).
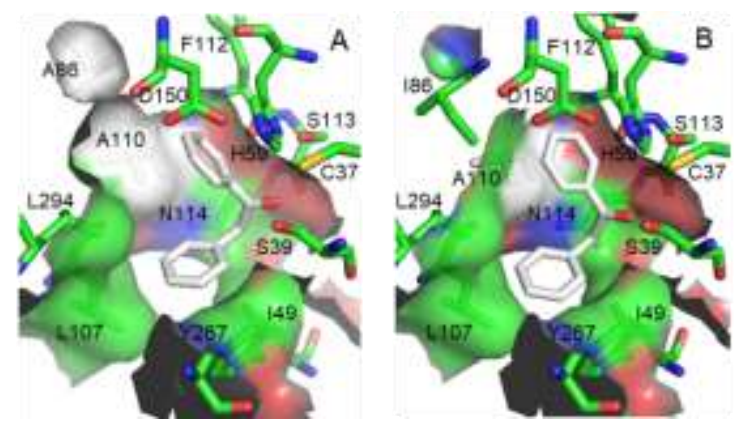
Figure 2. Lowest energy dockings of $1 \mathrm{~m}$ in the catalytic sites of $\mathrm{W} 110 \mathrm{~A} / \mathrm{l} 8 \mathrm{~A}$ TbSADH (A) and W110A TbSADH (B). The substrate is viewed from the face occupied by NADP in the TbSADH crystal structure. The residues lining up the binding pocket and those in close proximity to the reactive ketone are shown in stick representation. Colors are based on atoms (green or white: carbon; blue: nitrogen; red: oxygen; and yellow: sulfur). Mutated residues are in white. The surface of the binding pocket is shown when it does not hide the substrate.

A highly advantageous characteristic of enzymes, besides their high enantioselectivity, is their high regioselectivity. This very important feature, which is not easy to accomplish in organometallic or organic catalysis, was observed in the asymmetric reduction of 1-phenyl-1,2-propanedione (1n) and 1phenyl-1,3-butanedione (10). While 1n was not a substrate for TeSADH single W110 mutants, W110A/I86A TeSADH activity with $1 \mathrm{n}$ resulted in a regioselective reduction of the homobenzylic carbonyl to produce $(R)$-2-hydroxy-1-phenyl-1-propanone $[(R)$ 2n] with excellent conversion yield and enantioselectivity (Table 4). Production of the $R$ alcohol indicates that $\mathbf{1 n}$ fits in an orientation that allows for a Si-facial attack of the carbonyl (i.e., anti-Prelog mode). This stereochemical outcome is similar to that obtained in the $\mathrm{W} 110 \mathrm{~A} / \mathrm{I86A}$ TeSADH-catalyzed reduction of $\mathbf{1 f}$ and $\mathbf{1 g}$ (Table 2), which reflects the similarity of the three structures. In contrast, excellent performance was observed for all enzyme mutants in the regioselective asymmetric reduction of 10 in Prelog mode, predominantly yielding (S)-3-hydroxy-1phenyl-1-butanone $[(S)-20]$ and leaving the benzylic carbonyl intact.

Table 4. Asymmetric reduction of phenyl ring-containing ketones by the TeSADH mutants. ${ }^{[a]}$

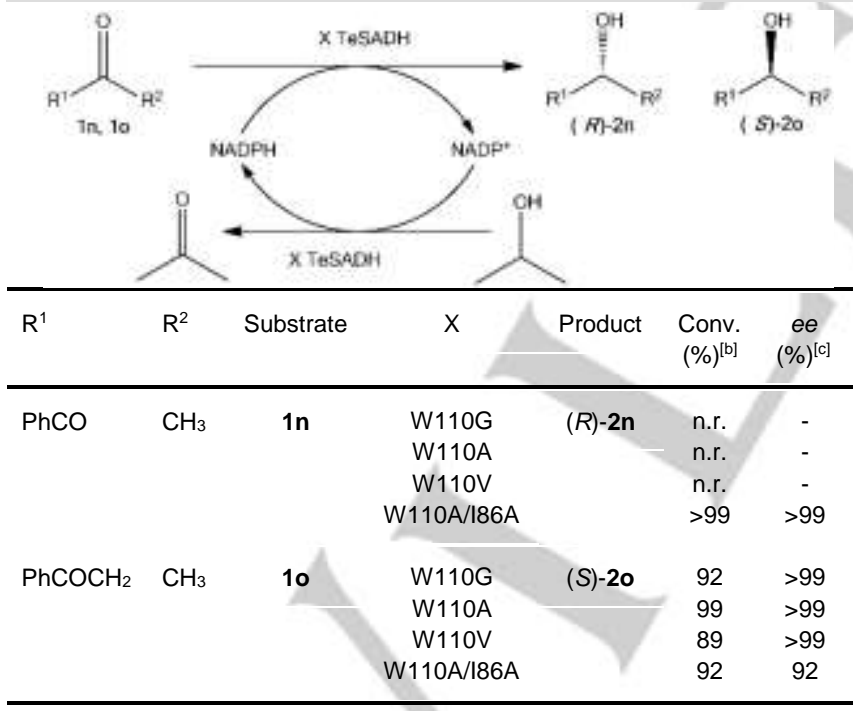

[a] Reactions were performed using $0.0191 \mathrm{mmol}$ ketones (1n, 10), $0.2 \mathrm{mg}$ enzyme, $1.0 \mathrm{mg} \mathrm{NADP}{ }^{+}, 700 \mu \mathrm{L}$ buffer $\mathrm{A}$, and $300 \mu \mathrm{L}$ 2-propanol; for W110A/l86A TeSADH-catalyzed reactions, $\mathrm{ZnCl}_{2}$ and DTT were added at $1.4 \mu \mathrm{M}$ and $6.5 \mathrm{mM}$ final concentrations, respectively; the W110V TeSADHcatalyzed reactions contained $0.0038 \mathrm{mmol}$ ketone, $950 \mu \mathrm{L}$ buffer $\mathrm{A}$, and 50 $\mu \mathrm{L} 2$ 2-propanol. [b] Percent conversion was determined by GC. [c] The \% ee of the acetate ester derivative of the alcohol produced was determined by GC using a chiral stationary phase. [n.r.: no reaction].

\section{Conclusions}

We showed that the $\mathrm{W} 110 \mathrm{~A} / \mathrm{I86A}$ double mutation expanded the substrate scope of TeSADH. This double mutant accommodates and reduces ketones that are substrates for W110 mutants only and others that are substrates for I86A TeSADH only, with conversion yields and enantioselectivities comparable to those obtained with the single mutants. W110A/I86A TeSADH accommodates $1 \mathrm{~m}$, whcih bears bulky groups on each side of the carbonyl, and reduces it with high conversion yield and enantioselectivity. W110A/I86A TeSADH showed a reverse enantiopreference for a few substrates, compared to the TeSADH single W110 mutants. We also succeeded in conducting regioselective reductions of diketones using both the TeSADH double and single mutants, a feature that is tough to accomplish by non-enzymatic approaches. The ability of $\mathrm{W} 110 \mathrm{~A} / \mathrm{I} 6 \mathrm{~A}$ TeSADH to accommodate a wider scope of substrates than those accommodated by wild-type TeSADH and other previously reported single mutants is of great interest to organic chemists.

\section{Experimental Section}

General: NADP + , NADPH, ketones 1a-e and 1g-o, (rac)-2a, (rac)-2f, (rac)2l, $(R)-\mathbf{2} \mathbf{a},(S)-\mathbf{2} \mathbf{a},(R)-\mathbf{2 f}$, and $(S)-\mathbf{2 f}$ were purchased from Sigma-Aldrich and used without further purification. (rac)-2b-e, (rac)-2g-k, and (rac)-2m were produced by $\mathrm{NaBH}_{4}$ reduction of their corresponding ketones as reported. ${ }^{[29 a]}$ All $\mathrm{pHs}$ were adjusted at room temperature. Nuclear Magnetic Resonance (NMR) spectra were recorded on a $500 \mathrm{MHz}$ spectrometer at $500 \mathrm{MHz}\left({ }^{1} \mathrm{H}\right)$ and at $125 \mathrm{MHz}\left({ }^{13} \mathrm{C}\right)$ at room temperature using either Tetramethylsilane (TMS) or the solvent peak as an internal standard. Optical rotation measurements were performed by using MCP 200 polarimeter.

Gene expression and purification of TeSADH mutants: W110A, W110G, W110V, and W110A/I86A mutants of TeSADH with a C-terminal His-tag were expressed and purified as previously reported.[27] In brief, proteins were expressed in Escherichia coli BL21 (DE3) (Novagen) grown in LB containing $100 \mu \mathrm{g} / \mathrm{mL}$ ampicillin. Two-L liquid cultures at an OD600 of 1.0 were induced with isopropyl $\beta$-D-1-thiogalactopyranoside for three hours. Once resuspended in lysis buffer, the cell pellet was lysed by high pressure differential lysis (Cell disruptor, Constant Systems), followed by centrifugation. The supernatant was heat-treated at $85{ }^{\circ} \mathrm{C}$ for $15 \mathrm{~min}$ to denature proteins from E. coli and centrifuged at $96,000 \mathrm{~g}$ for $40 \mathrm{~min}$. Finally, the proteins were purified by Ni-affinity chromatography ( HisTrap FF $5 \mathrm{~mL}$, GE Healthcare). The purified enzymes were dialyzed against 20 $\mathrm{mM}$ Tris- $\mathrm{HCl}(\mathrm{pH} 8.0$ ) containing $10 \mathrm{mM}$ 2-mercaptoethanol and $50 \%$ glycerol) and stored at $-80{ }^{\circ} \mathrm{C}$ until used. Protein concentrations were determined by $\mathrm{OD}_{280}$ using the extinction coefficient and molecular weight calculated based on the amino acid sequence composition of TeSADH.

General procedure for asymmetric reduction of ketones: Enzyme reaction mixtures contained $0.2 \mathrm{mg}$ enzyme and $1.0 \mathrm{mg} \mathrm{NADP}+$ in $100 \mu \mathrm{L}$ Tris- $\mathrm{HCl}(50 \mathrm{mM}, \mathrm{pH} 8.0$, buffer A), $600 \mu \mathrm{L}$ buffer A, $300 \mu \mathrm{L}$ 2-propanol, and $0.0191 \mathrm{mmol}$ ketone (1a-o). Reactions were started by adding the ketone. The mixture was incubated in a thermostated shaker maintained at $50{ }^{\circ} \mathrm{C}$ and $180 \mathrm{rpm}$. W110V TeSADH-catalyzed reactions were carried out using $0.00382 \mathrm{mmol}$ ketones in reaction mixtures containing $5 \% 2$ propanol (v/v). W110A/I86A TeSADH-catalyzed reactions were performed in the presence of $1.4 \mu \mathrm{M} \mathrm{ZnCl}_{2}$ and $6.5 \mathrm{mM}$ DDT. In a few cases, enzyme loading and 2-propanol concentrations were varied to achieve maximum 
conversions. Upon achieving maximum conversion to alcohol products (monitored by GC), the reaction mixture was extracted with ethyl acetate $(2 \times 500 \mu \mathrm{L})$. The combined organic layers were dried with sodium sulfate, and then concentrated. The remaining residue was treated with acetic anhydride (one drop) and pyridine (two drops) to obtain the acetate ester derivative prior to percent ee determination by chiral GC. ${ }^{[29 b]}$ The percent ee of $(R)-2 \mathrm{~m}$ was determined by a chiral HPLC.

General procedure for large-scale asymmetric reduction of ketones: A mixture of $0.191 \mathrm{mmol}$ ketone, $7.0 \mathrm{~mL}$ buffer A, $3.0 \mathrm{~mL}$ 2-propanol, 100 $\mu \mathrm{L}$ enzyme [0.2-0.4 $\mathrm{mg}$ in buffer $\mathrm{A}]$ and $2 \mathrm{mg} \mathrm{NADP}^{+}$was placed in a 50 $\mathrm{mL}$ round-bottomed flask equipped with a condenser and a magnetic stirrer. The reaction mixture was stirred at $50{ }^{\circ} \mathrm{C}$ for $24 \mathrm{~h}$. It was then extracted with ethyl acetate $(2 \times 7 \mathrm{~mL})$. The combined organic layers were dried with sodium sulfate and then concentrated. A portion of the remaining residue was derivatized as described above prior to $\mathrm{GC}$ analysis. $(R)-1,2-$ Diphenylethanol $[(R)-2 \mathrm{~m}]$ was purified by flash chromatography using diethyl ether:hexane $(1: 3, v / v)$.

GC Analysis (chiral): The percent ee values of the acetate ester derivatives of alcohol products were determined using an Agilent 7890A capillary GC equipped with a flame ionization detector and an HP chiral20B column ( $30 \mathrm{~m}, 0.32 \mathrm{~mm}$ [i.d.], $0.25 \mu \mathrm{m}$ film thickness) using $\mathrm{He}$ as the carrier gas. The temperature program for $\mathbf{2 a} \mathbf{a}-\mathbf{d}, \mathbf{2 f}, \mathbf{2 h}, \mathbf{2 i}, \mathbf{2 j}, \mathbf{2 n}$, and $\mathbf{2 0}$ was set as: oven $70^{\circ} \mathrm{C}$ (initial, hold time $10 \mathrm{~min}$ ) to $180^{\circ} \mathrm{C}$ (final, hold time $20 \mathrm{~min}$ ) at $5^{\circ} \mathrm{C} / \mathrm{min}$ rate; injector $220^{\circ} \mathrm{C}$, detector $230^{\circ} \mathrm{C}$; and $15 \mathrm{~mL} / \mathrm{min}$ He flow. For $\mathbf{2 e}, \mathbf{2} \mathbf{g}$, and $\mathbf{2 k}$, the rate of the oven temperature change was $1.5^{\circ} \mathrm{C} / \mathrm{min}$. The injection volume was $1.0 \mu \mathrm{L}$ with split ratio of $10: 1$.

GC-mass spectrometry (MS) analysis (non-chiral): GC-MS analysis was conducted using Agilent GC model 7890A combined with Agilent 5975C Inert MSD with Triple-Axis Detector using capillary column [(5\% phenyl)-methylpolysiloxane, $30 \mathrm{~m} \times 320 \mu \mathrm{m} \times 0.25 \mu \mathrm{m}$ ]. The following temperature program was used for GC: oven $70{ }^{\circ} \mathrm{C}$ (initial, hold time 10 min) to $180^{\circ} \mathrm{C}$ (final, hold time $20 \mathrm{~min}$ ) at $5^{\circ} \mathrm{C} / \mathrm{min}$ rate; injector $220^{\circ} \mathrm{C}$; detector $230^{\circ} \mathrm{C}$, and $15 \mathrm{~mL} / \mathrm{min} \mathrm{He}$ flow. The injection volume was $1.0 \mu \mathrm{L}$ with split ratio 10:1.

HPLC Analysis: HPLC measurements were performed on a DionexUltiMate 3000 system equipped with a Chiralcel OD-H column (Daicel). The percent ee of (S)-1 $\mathbf{m}$ was determined using hexane/methanol (95:5, $\mathrm{v} / \mathrm{v})$ as the mobile phase.

Determination of absolute configuration: The absolute configurations of $(S)-\mathbf{2} \mathbf{a},(S)-\mathbf{2} \mathbf{f}$, and $(R)-\mathbf{2 f}$ were determined by co-injection on a chiral GC with their commercially available enantiopure forms. The absolute configurations of $(S)-\mathbf{2 b},{ }^{[14 b]}(S)-\mathbf{2 c},{ }^{[30]}(S)-2 \mathbf{d},{ }^{[14 b]}(S)-2 \mathbf{e},{ }^{[31]}(S)-2 \mathbf{i},{ }^{[27]}(S)$ $2 \mathbf{j},{ }^{[31]}$ and $(S)-20,{ }^{[14 b]}$ were demonstrated by co-injection with enantiopure alcohols produced by W110A TeSADH-catalyzed reduction of their corresponding ketones, which were reported to have $(S)$-configuration. The absolute configuration of $(R)$-I was determined by co-injection with enantiopure alcohol produced by I86A TeSADH-catalyzed reduction of acetophenone.[16] The absolute configurations of $(R)-\mathbf{2} \mathbf{g},(S)-\mathbf{2 g},(S)-\mathbf{2 h}$, $(R)-\mathbf{2 k},(S)-\mathbf{2} \mathbf{m}$, and $(R)-\mathbf{2} \mathbf{n}$ were determined by comparing the sign of optical rotation with those reported in literature.

Docking experiment: The 3D coordinates of $1 \mathrm{~m}$ were generated with CORINA-Gasteiger Research. Mutations were introduced in the structure of TbSADH complexed with NADP (PDB no. 1YKF) using PyMOL Molecular Graphics System, Version 1.8 (Schrödinger, LLC). The 3D structure of $1 \mathrm{~m}$ was docked in the $3 \mathrm{D}$ structures of the mutant enzymes with AutoDock Vina ${ }^{[32]}$ using a search box of $12 \AA \times 12 \AA$ x $12 \AA$ centered on the TbSADH catalytic $\mathrm{Zn}$ atom. Structures were visualized using PyMOL.
(S)-4-Phenyl-2-butanol [(S)-2a]: ${ }^{1} \mathrm{H} \mathrm{NMR}\left(\mathrm{CDCl}_{3}\right): \delta=1.23(\mathrm{~d}, J=6.1 \mathrm{~Hz}$, $3 \mathrm{H}), 1.59(\mathrm{~s}, 1 \mathrm{H}), 1.74-1.85(\mathrm{~m}, 2 \mathrm{H}), 2.67-2.81(\mathrm{~m}, 2 \mathrm{H}), 3.79-3.86(\mathrm{~m}$, $1 \mathrm{H}), 7.17-7.31(\mathrm{~m}, 5 \mathrm{H}) \mathrm{ppm} .{ }^{13} \mathrm{C} \mathrm{NMR}\left(\mathrm{CDCl}_{3}\right): \delta=23.8,32.3,41.1,67.8$, $126.1,128.6,128.7,142.4 \mathrm{ppm} .{ }^{1} \mathrm{H}$ and ${ }^{13} \mathrm{C}$ NMR data were in accordance with those previously reported. ${ }^{[33]}$

(S)-4-(4'-Methoxyphenyl)-2-butanol [(S)-2b]: ${ }^{1} \mathrm{H} \mathrm{NMR}\left(\mathrm{CDCl}_{3}\right): \delta=1.21$ $(\mathrm{d}, j=6.1 \mathrm{~Hz}, 3 \mathrm{H}), 1.46(\mathrm{br} \mathrm{s}, 1 \mathrm{H}), 1.69-1.78(\mathrm{~m}, 2 \mathrm{H}), 2.57-2.70(\mathrm{~m}, 2$ H), $3.76(\mathrm{~s}, 3 \mathrm{H}), 3.77-3.81(\mathrm{~m}, 1 \mathrm{H}), 6.81(\mathrm{~d}, J=8.3 \mathrm{~Hz}, 2 \mathrm{H}), 7.10(\mathrm{~d}, J=$ $8.3 \mathrm{~Hz}, 2 \mathrm{H}) \mathrm{ppm} .{ }^{13} \mathrm{C} \mathrm{NMR}\left(\mathrm{CDCl}_{3}\right): \delta=23.6,31.2,41.0,55.2,67.5,113.8$, $129.2,134.1,157.7 \mathrm{ppm} .{ }^{1} \mathrm{H}$ and ${ }^{13} \mathrm{C}$ NMR data were in accordance with those previously reported. ${ }^{[14 b]}$

(S)-4-(4'-Hydroxyphenyl)-2-butanol [(S)-2c]: ${ }^{1} \mathrm{H} \mathrm{NMR}\left(\mathrm{CD}_{3} \mathrm{OD}\right)$ : $\delta=1.18$ $(\mathrm{d}, J=6.1 \mathrm{~Hz}, 3 \mathrm{H}), 1.60-1.75(\mathrm{~m}, 2 \mathrm{H}), 2.50-2.59(\mathrm{~m}, 1 \mathrm{H}), 2.60-2.71(\mathrm{~m}$, $1 \mathrm{H}), 3.32(\mathrm{~s}, 1 \mathrm{H}), 3.68-3.76(\mathrm{~m}, 1 \mathrm{H}), 6.70(\mathrm{~d}, J=8.3 \mathrm{~Hz}, 2 \mathrm{H}), 7.01(\mathrm{~d}, J$ $=8.3 \mathrm{~Hz}, 2 \mathrm{H}) \mathrm{ppm} .{ }^{13} \mathrm{C} \mathrm{NMR}\left(\mathrm{CD}_{3} \mathrm{OD}\right): \delta=23.5,32.3,42.4,67.9,116.1$, $130.2,134.4,156.3 \mathrm{ppm} .{ }^{1} \mathrm{H}$ and ${ }^{13} \mathrm{C}$ NMR data were in accordance with those previously reported. ${ }^{[34]}$

(S)-4-Phenyl-3-buten-2-ol [(S)-2d]: ${ }^{1} \mathrm{H}$ NMR $\left(\mathrm{CDCl}_{3}\right): \delta=1.31$ (d, $J=6.4$ $2 \mathrm{H}), 1.63(\mathrm{br} \mathrm{s}, 1 \mathrm{H}), 4.39-4.47(\mathrm{~m}, 1 \mathrm{H}), 6.20(\mathrm{dd}, J=15.8,6.4 \mathrm{~Hz}, 1 \mathrm{H})$ $6.51(\mathrm{~d}, J=15.9 \mathrm{~Hz}, 1 \mathrm{H}), 7.18-7.33(\mathrm{~m}, 5 \mathrm{H}) \mathrm{ppm} .{ }^{13} \mathrm{C} \mathrm{NMR}\left(\mathrm{CDCl}_{3}\right): \delta=$ 23.4, 68.9, 126.4, 127.6, 128.6, 129.4, 133.5, $136.7 \mathrm{ppm} .{ }^{1} \mathrm{H}$ and ${ }^{13} \mathrm{C}$ NMR data were in accordance with those previously reported. ${ }^{[35]}$

(S)-4-Phenyl-3-butyn-2-ol [(S)-2e]: ${ }^{1} \mathrm{H}$ NMR $\left(\mathrm{CDCl}_{3}\right): \delta=1.56$ (d, $J=6.7$ $\mathrm{Hz}, 3 \mathrm{H}), 2.11$ (br s, $1 \mathrm{H}), 4.76(\mathrm{q}, J=6.7 \mathrm{~Hz}, 1 \mathrm{H}), 7.29-7.43(\mathrm{~m}, 5 \mathrm{H}) .{ }^{13} \mathrm{C}$ NMR $\left(\mathrm{CDCl}_{3}\right): \delta=24.4,58.8,84.0,90.9,122.6,128.2,128.3,131.6 \mathrm{ppm}$ ${ }^{1} \mathrm{H}$ and ${ }^{13} \mathrm{C}$ NMR data were in accordance with those previously reported. ${ }^{[36]}$

(S)-1-Phenyl-2-propanol [(S)-2f]: ${ }^{1} \mathrm{H}$ NMR $\left(\mathrm{CDCl}_{3}\right): \delta=1.27$ (d, $J=6.1$ $\mathrm{Hz}, 3 \mathrm{H}), 1.61$ (br s, $1 \mathrm{H}$ ), 2.71 (dd, $J=13.6,8.1 \mathrm{~Hz}, 1 \mathrm{H}), 2.81$ (dd, $J=$ $13.4,4.9 \mathrm{~Hz}, 1 \mathrm{H}), 4.01-4.08(\mathrm{~m}, 1 \mathrm{H}), 7.22-7.35(\mathrm{~m}, 5 \mathrm{H}) \mathrm{ppm} .{ }^{13} \mathrm{C} \mathrm{NMR}$ $\left(\mathrm{CDCl}_{3}\right): \delta=23.0,46.0,69.1,126.8,128.9,129.7,138.8 \mathrm{ppm} .{ }^{1} \mathrm{H}$ and ${ }^{13} \mathrm{C}$ NMR data were in accordance with those previously reported. ${ }^{[33]}$

(R)-1-(2'-Chlorophenyl)-2-propanol $\quad[(\boldsymbol{R})-2 \mathrm{~g}]:\left[\begin{array}{lll}{[\alpha]_{D}^{21}} & -20^{\circ} & (c 0.011\end{array}\right.$ $\left.\mathrm{CH}_{2} \mathrm{Cl}_{2}\right) 99 \%$ ee, lit. ${ }^{[37]}[\alpha]_{D}^{20}+40.3\left(c 1.0, \mathrm{CH}_{2} \mathrm{Cl}_{2}\right), 95 \%$ ee for $S$ isomer ${ }^{1} \mathrm{H} \mathrm{NMR}\left(\mathrm{CDCl}_{3}\right): \delta=1.27(\mathrm{~d}, J=6.1 \mathrm{~Hz}, 3 \mathrm{H}), 2.83(\mathrm{dd}, J=13.7,7.9 \mathrm{~Hz}$ $1 \mathrm{H}), 2.96(\mathrm{dd}, J=13.6,4.6 \mathrm{~Hz}, 1 \mathrm{H}), 4.12-4.16(\mathrm{~m}, 1 \mathrm{H}), 7.17-7.38(\mathrm{~m}, 4$ H) ppm. ${ }^{13} \mathrm{C} \mathrm{NMR}\left(\mathrm{CDCl}_{3}\right): \delta=23.0,43.2,67.5,126.8,127.9,129.6,131.7$, 134.3, 136.4 ppm. ${ }^{1} \mathrm{H}$ and ${ }^{13} \mathrm{C}$ NMR data were in accordance with those previously reported. ${ }^{[37]}$

(S)-1-(4'-Chlorophenyl)-2-propanol [(S)-2h]: $[\alpha]_{D}^{21}+7.7^{\circ} \quad(c 0.011$, $\left.\mathrm{CHCl}_{3}\right)>99 \%$ ee, lit. ${ }^{[38]}[\alpha]_{D}^{25}+31\left(\mathrm{c} 1.0, \mathrm{CHCl}_{3}\right),>99 \%$ for $S$ isomer. ${ }^{1} \mathrm{H}$ $\operatorname{NMR}\left(\mathrm{CDCl}_{3}\right): \delta=1.17(\mathrm{~d}, J=6.4 \mathrm{~Hz}, 3 \mathrm{H}), 2.6(\mathrm{dd}, J=13.6,7.6 \mathrm{~Hz}, 1 \mathrm{H})$, 2.68 (dd, $J=13.4,4.9 \mathrm{~Hz}, 1 \mathrm{H}), 3.92-3.95(\mathrm{~m}, 1 \mathrm{H}), 7.08(\mathrm{~d}, J=8.2 \mathrm{~Hz}, 2$ $\mathrm{H}), 7.20(\mathrm{~d}, J=8.2 \mathrm{~Hz}, 2 \mathrm{H}) \mathrm{ppm} .{ }^{13} \mathrm{C} \mathrm{NMR}\left(\mathrm{CDCl}_{3}\right): \delta=22.9,44.9,68.7$, $128.6,130.7,132.3,137.0 \mathrm{ppm} .{ }^{1} \mathrm{H}$ and ${ }^{13} \mathrm{C}$ NMR data were in accordance with those previously reported. ${ }^{[38]}$

(S)-1-[(3'-Trifluoromethyl)-phenyl)]-2-propanol [(S)-2i]: ${ }^{1} \mathrm{H} \quad$ NMR $\left(\mathrm{CDCl}_{3}\right): \delta=1.26(\mathrm{~d}, J=6.1 \mathrm{~Hz}, 3 \mathrm{H}), 1.70(\mathrm{br} \mathrm{s}, 1 \mathrm{H}), 2.78(\mathrm{dd}, J=13.7$ $7.9 \mathrm{~Hz}, 1 \mathrm{H}), 2.84$ (dd, $J=13.4,4.6 \mathrm{~Hz}, 1 \mathrm{H}), 4.03-4.09(\mathrm{~m}, 1 \mathrm{H}), 7.40-$ $7.51(\mathrm{~m}, 4 \mathrm{H})$ ppm. ${ }^{13} \mathrm{C} \mathrm{NMR}\left(\mathrm{CDCl}_{3}\right): \delta=22.9,45.3,68.6,123.3$ (q, Jc-F $=$ $3.1 \mathrm{~Hz}$ ), 124.1 (q, Jc-F = 270.3 Hz), 126.0 (q, Jc-F = 3.1 Hz), 128.9, 130.7 (q, $\mathrm{J}_{\mathrm{C}-\mathrm{F}}=32 \mathrm{~Hz}$ ), 132.8, $139.5 \mathrm{ppm} .{ }^{1} \mathrm{H}$ and ${ }^{13} \mathrm{C}$ NMR data were in accordance with those previously reported. ${ }^{[33]}$ 
(S)-1-Phenyl-2-butanol [(S)-2j]: ${ }^{1} \mathrm{H}$ NMR $\left(\mathrm{CDCl}_{3}\right): \delta=1.01(\mathrm{t}, J=7.3 \mathrm{~Hz}$, $3 \mathrm{H}$ ), 1.49-1.60 (m, $3 \mathrm{H}$ ), 2.60 (dd, $J=13.5,8.4 \mathrm{~Hz}, 1 \mathrm{H}$ ), 2.85 (dd, $J=13.5$, $4.3 \mathrm{~Hz}, 1 \mathrm{H}), 3.71-3.78(\mathrm{~m}, 1 \mathrm{H}), 7.21-7.63(\mathrm{~m}, 5 \mathrm{H}) \mathrm{ppm} .{ }^{13} \mathrm{C}$ NMR $\left(\mathrm{CDCl}_{3}\right): \delta=10.0,29.6,43.6,74.0,126.4,128.5,129.4,138.6 \mathrm{ppm} .{ }^{1} \mathrm{H}$ and ${ }^{13} \mathrm{C}$ NMR data were in accordance with those previously reported. ${ }^{[35]}$

(R)-1-Phenyl-2-pentanol [( $R$ )-2k]: $[\alpha]_{D}^{21}-1.01^{\circ}(c 0.015$, EtOH) $98 \%$ ee, lit. ${ }^{[39]}[\alpha]_{D}^{20}+3.7^{\circ}\left(c 1.1\right.$, EtOH), $99 \%$ ee for $S$ isomer. ${ }^{1} \mathrm{H} \mathrm{NMR}\left(\mathrm{CDCl}_{3}\right): \delta=$ $0.94(\mathrm{t}, J=7.0 \mathrm{~Hz}, 3 \mathrm{H}), 1.41-1.55(\mathrm{~m}, 4 \mathrm{H}), 2.65(\mathrm{dd}, J=13.6 \mathrm{~Hz}, 8.5 \mathrm{~Hz}$ $1 \mathrm{H}), 2.83$ (dd, $J=13.6 \mathrm{~Hz}, 4.0 \mathrm{~Hz}, 1 \mathrm{H}$ ), 3.67 (br s, OH), 3.81-3.86 (m, $1 \mathrm{H}), 7.21-7.35(\mathrm{~m}, 5 \mathrm{H}) \mathrm{ppm} .{ }^{13} \mathrm{C} \mathrm{NMR}\left(\mathrm{CDCl}_{3}\right): \delta=14.0,18.9,39.1,44.1$, $72.4,126.4,128.5,129.4,138.6 \mathrm{ppm} .{ }^{1} \mathrm{H}$ and ${ }^{13} \mathrm{C}$ NMR data were in accordance with those previously reported. ${ }^{[40]}$

( $\boldsymbol{R})$-1-Phenyl-1-ethanol [( $\boldsymbol{R})$-2l]: ${ }^{1} \mathrm{H}$ NMR $\left(\mathrm{CDCl}_{3}\right): \delta=1.47(\mathrm{~d}, J=6.4 \mathrm{~Hz}$, $3 \mathrm{H}), 2.2(\mathrm{br} \mathrm{s}, 2 \mathrm{H}), 4.86(\mathrm{q}, J=6.4,1 \mathrm{H}), 7.25-7.36(\mathrm{~m}, 5 \mathrm{H}) .{ }^{13} \mathrm{C}$ NMR $\left(\mathrm{CDCl}_{3}\right): \delta=25.1,70.3,125.3,127.4,128.4,145.7 .{ }^{1} \mathrm{H}$ and ${ }^{13} \mathrm{C}$ NMR data were in accordance with those previously reported. ${ }^{[33]}$

(R)-1,2-Diphenylethanol [(R)-2m]: $[\alpha]_{D}^{24}+7.4^{\circ}\left(c 0.016, \mathrm{CHCl}_{3}\right) 95 \%$ ee, lit. ${ }^{[41]}[\alpha]_{D}^{22}-13.0\left(c 1.05, \mathrm{CHCl}_{3}\right), 90 \%$ ee for $S$ isomer. ${ }^{1} \mathrm{H} \mathrm{NMR}\left(\mathrm{CDCl}_{3}\right)$ : $\delta=1.93(\mathrm{br} \mathrm{s}, 1 \mathrm{H}$ ), 2.99 (dd, $J=13.7,8.6 \mathrm{~Hz}, 1 \mathrm{H}$ ), 3.05 (dd, $J=13.6,4.6$ $\mathrm{Hz}, 1 \mathrm{H}), 4.88-4.92(\mathrm{~m}, 1 \mathrm{H}), 7.19-7.37(\mathrm{~m}, 10 \mathrm{H}) \mathrm{ppm} .{ }^{13} \mathrm{C} \mathrm{NMR}\left(\mathrm{CDCl}_{3}\right)$ : $\delta=46.1,75.3,125.9,126.6,127.6,128.4,128.5,129.5,138.0,143.8$ ppm. ${ }^{1} \mathrm{H}$ and ${ }^{13} \mathrm{C}$ NMR data were in accordance with those previously reported. ${ }^{[41,42]}$

(R)-2-Hydroxy-1-phenyl-1-propanone [(R)-2n]: $[\alpha]_{D}^{21}-4.8^{\circ}$ (c 0.0075, $\left.\mathrm{CHCl}_{3}\right)>99 \%$ ee, lit. ${ }^{[43]}[\alpha]_{D}^{20}-67.0\left(c 0.4, \mathrm{CHCl}_{3}\right),>99 \%$ ee for $R$ isomer. ${ }^{1} \mathrm{H} \mathrm{NMR}\left(\mathrm{CDCl}_{3}\right): \delta=1.46(\mathrm{~d}, J=7.0 \mathrm{~Hz}, 3 \mathrm{H}), 3.7(\mathrm{~s}, 1 \mathrm{H}), 5.17(\mathrm{q}, J=7.6$ $\mathrm{Hz}, 1 \mathrm{H}), 7.48-7.53(\mathrm{~m}, 2 \mathrm{H}), 7.62-7.65(\mathrm{~m}, 1 \mathrm{H}), 7.92-7.95(\mathrm{~m}, 2 \mathrm{H}) \mathrm{ppm}$. ${ }^{13} \mathrm{C} \mathrm{NMR}\left(\mathrm{CDCl}_{3}\right): \delta=22.3,69.3,128.7,128.9,133.4,134.0,202.4 \mathrm{ppm}$. ${ }^{1} \mathrm{H}$ and ${ }^{13} \mathrm{C}$ NMR data were in accordance with those previously reported. ${ }^{[44]}$

\section{Acknowledgements}

The authors acknowledge the support provided by the Deanship of Scientific Research (DSR) at King Fahd University of Petroleum and Minerals (KFUPM) for funding this work under project number IN151032. They also acknowledge the supported by baseline research fund to S.M.H. by King Abdullah University of Science and Technology.

Keywords: active site $\cdot$ alcohol dehydrogenases $\cdot$ asymmetric reduction $\bullet$ site-directed mutagenesis $\cdot$ substrate specificity

[1] U. T. Bornscheuer, G. W. Huisman, R. J. Kazlauskas, S. Lutz, J. C. Moore, K. Robins, Nature 2012, 485, 185-194.

[2] K. Faber, Biotransformations in organic chemistry, $6^{\text {th }}$ ed., Springer Verlag, New York, 2011.

[3] a) Y. Ni, J. Xu, Biotechnol. Adv. 2012, 30, 1279-1288; b) L. Wang, C. Li, Y. Ni, J. Zhang, X. Liu, J. Xu, Bioresour. Technol. 2011, 102, 7023-7028; c) G. W. Huisman, J. Liang, A. Krebber, Curr. Opin. Chem. Biol. 2010 , 14, 122-129; d) G. A. Strohmeier, H. Pichler, O. May, M. GruberKhadjawi, Chem. Rev. 2011, 111, 4141-4164.

[4] R. Agudo, G.-D. Roiban, M. T. Reetz, J. Am. Chem. Soc. 2013, 135, 1665-1668.

[5] a) I. Lavandera, G. Oberdorver, J. Gross, S. De Wildeman, W. Kroutil, Eur. J. Org. Chem. 2008, 2539-2543; b) K. Edegger, W. Stampfer, B.
Seisser, K. Faber, S. F. Mayer, R. Oehlein, A. Hafner, W. Kroutil, Eur. J. Org. Chem. 2006, 1904-1909.

[6] D. Zhu, Y. Yang, L. Hua, J. Org. Chem. 2007, 71, 4202-4205.

[7] H. Gröger, F. Chamouleau, N. Orologas, C. Rollman, K. Drauz, W. Haummel, A. Weckbecker, O. May, Angew. Chem. Int. Ed. 2006, 45 5677-5681; Angew. Chem. 2006, 118, 5806-5809.

[8] J. Grunwald, B. Wirz, M. P. Scollar, A. M. Klibanov J. Am. Chem. Soc 1986, 108, 6734-6739

[9] O. Bsharat, M. M. Musa, C. Vieille, S. A. Oladepo, M. Takahashi, S. M. Hamdan, ChemCatChem 2017, 9, 1487-1493.

[10] a) C. Heiss, R. S. Phillips, J. Chem. Soc., Perkin Trans. 2000, 1, $2821-$ 2825; b) C. Heiss, M. Laivenieks, J. G. Zeikus, R. S. Phillips Biorg. Med. Chem. 2001, 9, 1659-1666.

[11] E. Keinan, E. Hafeli, K. K. Seth, R. Lamed, J. Am. Chem.Soc. 1986, 108 162-169.

[12] a) D. Burdette, J. G. Zeikus, Biochem. J. 1994, 302, 163-170; b) D. Burdette, C. Vieille, J. G. Zeikus, Biochem. J. 1996, 316, 115-122; c) V. T. Pham, R. S. Phillips, J. Am. Chem. Soc. 1990, 112, 3629-3632.

[13] C. M. Nealon, M. M. Musa, J. M. Patel, R. S. Phillips, ACS Catal. 2015 5, 2100-2114

[14] a) J. M. Patel, M. M. Musa, L. Rodriguez, D. A. Sutton, V. Popik, R. S. Phillips, Org. Biomol. Chem. 2014, 12, 5905-5910; b) M. M. Musa, K. I. Ziegelmann-Fjeld, C. Vieille, J. G. Zeikus, R. S. Phillips, J. Org. Chem. 2007, 72, 30-34; c) K. I. Ziegelmann-Fjeld, M. M. Musa, R. S. Phillips, J. G. Zeikus, C. Vieille, Protein Eng. Des. Sel. 2007, 20, 47-55.

[15] V. Prelog, Pure Appl. Chem. 1964, 9, 119-130.

[16] M. M. Musa, N. Lott, M. Laivenieks, L. Watanabe, C. Vieille, R. S. Phillips ChemCatChem 2009, 1, 89-93.

[17] a) G. R. Petit, S. B. Singh and G. M. Cragg, J. Org. Chem. 1985, 50 3404-3406; b) A. Ramacciotti, R. Fiaschi, E. Napolitano, Tetrahedron: Asymmetry 1996, 7, 1101-1104.

[18] a) F. Li, J. Cui, X. Qian, W. Ren, X. Wang, Chem. Commun. 2006, 865 867 ; b) C. Hiraoka, M. Matsuda, Y. Suzuki, S. Fujieda, M. Tomita, K Fuhshuku, R. Obata, S. Nishiyama, T. Sugai, Tetrahedron: Asymmetry 2006, 17, 3358-3367.

[19] a) S. Roy, V. Alexandre, M. Neuwels, L. Le Texier, Adv. Synth. Catal. 2001, 343, 738-743; b) D. Zhu, L. Hua, J. Org. Chem. 2006, 71, 9484 9486; c) M. D. Truppo, D. Pollard, P. Devine, Org. Lett. 2007, 9, 335338; d) R. R. Manam, V. R. Macherla, B. C. M. Potts, Tetrahedron Lett 2007, 48, 2537-2540; e) H. Li, D. Zhu, L. Hua, E. R. Biehl, Adv. Synth Catal. 2009, 351, 583-588; f) J. Liang, J. Lalonde, B. Borup, V. Mitchell, E. Mundorff, N. Trinh, D. A. Kochrekar, R. N. Cherat, G. G. Pai, Org. Process Res. Dev. 2010, 14, 193-198.

[20] Reaction conditions used in ref. $14 \mathrm{~b}$ for asymmetric reductions of $\mathbf{1 a}, \mathbf{1 b}$ 1d, and 1f: $0.34 \mathrm{mmol}$ substrate, $2.0 \mathrm{mg} \mathrm{NADP}^{+}, 0.75 \mathrm{mg} \mathrm{W110A}$ TeSADH, $7.0 \mathrm{~mL}$ Tris- $\mathrm{HCl}(50 \mathrm{mM}, \mathrm{pH} 8.0)$, and $3.0 \mathrm{~mL}$ 2-propanol. Reaction conditions used in ref. 14a for asymmetric reductions of $1 \mathrm{a}$ and 1f: $0.04 \mathrm{mmol}$ ketone, $1.0 \mathrm{mg} \mathrm{NADP}+0.35 \mathrm{mg}$ mutant TeSADH, $9.5 \mathrm{~mL}$ Tris- $\mathrm{HCl}(50 \mathrm{mM}, \mathrm{pH} 8.0)$, and $0.5 \mathrm{~mL}$ 2-propanol.

[21] N. Shibata, T. Katoh, S. Terashima, Tetrahedron lett. 1997, 38, 619-620.

[22] T. Fujita, Phytochemistry 1995, 39, 1085-1089.

[23] Y. Yuasa, S. Shibuya, Y. Yuasa, Synth. Commun. 2003, 33, 1469-1475

[24] K. Matsumura, S. Hashigushi, T. Ikariya, R. Noyori, J. Am. Chem. Soc. 1997, 119, 8738-8739.

[25] Z. Zhang, P. Jain, J. C. Antilla, Angew. Chem. Int. Ed. 2011, 50, 10961 10964; Angew. Chem. 2011, 123, 11153-11156.

[26] a) I. L. Schmitke, L. J. Stern, A. M. Klibanov, Proc. Natl. Acad. Sci. U.S.A. 1998, 95, 12918-12923; b) C. Heiss, M. Laivenieks, J. G. Zeikus, R. S Phillips, J. Am. Chem. Soc. 2001, 123, 345-346.

[27] I. Karume, M. Takahashi, S. M. Hamdan, M. M. Musa, ChemCatChem 2016, 8, 1458-1463.

[28] Acetophenone and its derivatives are not substrates for W110 single mutants of TeSADH. We coud not explain the absence of activity of the W110 single mutants on acetophenone with computational docking 
because docking studies do not take into consideration the effect of mutations on the enzyme's structure.

[29] a) V. K. Yadav, K. G. Babu, Tetrahedron 2003, 59, 9111-9116; b) A Ghanem, V. Schurig, Tetrahedron: Asymmetry 2003, 14, 57-62.

[30] M. M. Musa, Asian J. Chem. 2014, 26, 6719-6721.

[31] M. M. Musa, Asian J. Chem. 2014, 26, 8363-8365

[32] O. Trott, A. J. Olson, J. Comput. Chem. 2010, 31, 455-461.

[33] P. Vitale, V. M. Abbinante, F. M. Perna, A. Salomone, C. Cardellicchio, V. Capriati, Adv. Synth. Catal. 2017, 359, 1049-1057.

[34] Y. Yuasa, S. Shibuya, Y. Yuasa, Synth. Commun. 2003, 33, 1469-1475

[35] T. Slagbrand, H. Lundberg, H. Adolfsson, Chem. Eur. J. 2014, 20, 16102 16106.

[36] T. Schubert, W. Hummel, M.-R. Kula, M. Müller, Eur. J. Org. Chem. 2001, 4181-4187.

[37] J. Mangas-Snchez, E. Busto, V. Gotor-Fernndez, V. Gotor, Org. Lett. 2010, 12, 3498-3501.

[38] B. Erdélyi, A. Szabo, G. Seres, L. Birincsik, J. Ivanics, G. Szatzker, L. Poppe, Tetrahedron Asymmetry 2006, 17, 268-274.

[39] B. Kang, R. Britton, Org. Lett. 2007, 9, 5083-5086.

[40] U. P. Dhokte, P. M. Pathare, V. K. Mahindroo, H. C. Brown, J. Org. Chem. 1998, 63, 8276-8283.

[41] A. Tschöp, M. V. Nandakumar, O. Pavlyuk, C. Schneider, Tetrahedron Lett. 2008, 49, 1030-1033.

[42] X. Wu, X. Li, A. Zanotti-Gerosa, A. Pettman, J. Liu, A. J. Mills, J. Xiao, Chem. Eur. J. 2008, 14, 2209-2222.

[43] B. M. Nestl, W. Kroutil, K. Faber, Adv. Synth. Catal. 2006, 348, 873-876.

[44] E. Lourenço, J. A. Rodrigues, P. J. S. Moran, J. Mol. Catal. B Enzym. 2004, 29, 37-40. 
WILEY-VCH

\section{FULL PAPER}

\section{Entry for the Table of Contents}

\section{FULL PAPER}

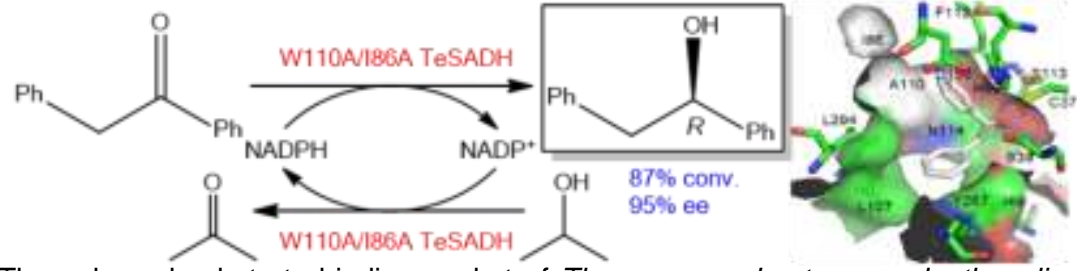

The enlarged substrate binding pocket of Thermoanaerobacter pseudoethanolicus secondary alcohol dehydrogenase W110A/l86A double mutant (W110A/I86A TeSADH) enabled the asymmetric reduction of ketones bearing two sterically demanding groups. W110A/I86A TeSADH also reduced ketones that are substrates for W110A TeSADH single mutant in high enantioselectivity.
Author(s), Corresponding Author(s)* Musa M. Musa, * Odey Bsharat, Ibrahim Karume, Claire Vieille, Masateru Takahashi, and Samir M. Hamdan

\section{Page No. - Page No.}

Expanding the Substrate Specificity of Thermoanaerobacter pseudoethanolicus Secondary Alcohol Dehydrogenase by a Dual Site Mutation 